Nalar: Jurnal Peradaban dan Pemikiran Islam

Vol. 2, No. 2, Desember 2018

\title{
Sejarah Perkembangan Globalisasi dalam Dunia Islam
}

\author{
Budi Sujati \\ Pascasarjana Universitas Islam Negeri Sunan Gunung Djati Bandung \\ budisujati@gmail.com
}

\begin{tabular}{ll}
\hline & Abstrak \\
\hline Article History: & Di era globalisasi ini, semua informasi yang berkaitan dengan isu-isu \\
Received :12-10-2018 & kontemporer sangat menarik untuk dikaji. Dalam diskursus itu \\
Revised :21-11-2018 & memunculkan realita dari fakta yang ada mengenai perkembangan \\
Accepted:28-11-2018 & globalisasi dari zaman kuno hingga zaman modern menarik untuk \\
\hline Kata Kunci: & dikaji dalam tulisan ini. Pendekatan yang digunakan dalam \\
Globalisasi, & globalisasi adalah fenomenologi dengan melibat suatu peristiwa harus \\
Universal. & dilihat dari fenomena-fenomena yang terjadi saat ini secara global. \\
Islam, & Islam sebagai agamayang memiliki tatanan universal dan global, tentu \\
Kontemporer. & memiliki peran dalam menyelesaikan masalah globalisasi. Yang jelas \\
& dari universalitasnya, Islam dapat memiliki peran penting untuk \\
& membentuk komunitas global. Dari sinilah, universalitas Islam \\
& mampu menghadapi masalah-masalahyang menghadangnya. \\
\hline
\end{tabular}

\section{Pendahuluan}

Diskursus mengenai globalisasi sudah mulai muncul sekira dekade 1990-an, era itu dikenal sebagai era globalisasi (the age of globalization). Kemunculan isu-isu seputar diskursus globalisasi pada masa ini tidak terlepas dari dua hal, yaitu sebagai akibat dari runtuhnya Negara Uni Soviet usai perang dingin pada 1991 dan peran perkembangan teknologi dan informasi yang semakin pesat dan maju. Dengan keruntuhan salah satu ideologi yang tertutup dan teknologi yang semakin maju itu, semakin memudahkan manusia untuk mengakses arus informasi dari berbagai belahan dunia tanpa adanya ruang spasial dan temporar yang merintang. Meski berangkat dari persoalan tersebut, globalisasi tidak hanya berkelindan dengan pesatnya teknologi dan informasi saja, tetapi juga berkaitan dengan persoalan-persoalan yang lain seperti: pendidikan, agama, sosial, politik, budaya, ilmu pengetahuan, teknologi, dan lain sebagainya.

Sebagaimana yang diungkapkan oleh Uskup Agung Wulsftan, dalam khotbahnya di New York pada 2014, "Dunia bergerak dengan cepat dan tengah mendekati titik nadirnya". Mudah dibayangkan bahwa perasaan yang sama juga diungkapkan pada zaman sekarang. Apakah harapan dan kegelisahan di setiap periode hanyalah salinan dari masa-masa sebelumnya? Apakah dunia tempat kita hidup di akhir abad ke-20 ini sunggguh berbeda dengan waktu-waktu sebelumnya? (Jones, Bradburry, dan Le Boutillier 2016:263). Banyak kegelisahan yang muncul menyertai setiap perubahan yang terjadi, terlebih ketika globalisasi dianggap telah menjadi momok yang dirasa sangat menakutkan karena pengaruhnya luar biasa dalam merombak struktur kehidupan manusia, baik secara personal maupun dalam kehidupan kolektif masyarakat, berbangsa, dan bernegara (Khotimah 2009:114).

Kegelisahan yang menyelimuti dunia dengan hadirnya globalisasi yang harus dihindari denga sudut pandang yang progresif. Globalisasi merupakan jalannya sejarah yang harus disikapi dengan bijaksana, terlebih bagi umat muslim yang sudah memiliki tatanan ajaran yang mampu menghadapi badai perkembangan hingga masa sekarang. 
Nalar: Jurnal Peradaban dan Pemikiran Islam

Vol. 2, No. 2, Desember 2018

Oleh karena itu, Islam harus bisa menghadapi tantangan dan jawaban (challenge and response) seperti yang dicetuskan oleh Arnold Toynbee mengenai teorinya, bahwa setiap ada permasalahan pasti ada jawabannya dari masyarakat. Seyogyanya, umat muslim sebagai masyarakat dunia dengan konsep-konsep Islam yang sudah dicetuskan oleh Muhammad mengenai ajaran-ajaran Islam yang bersifat universal dengan ditegakannya prinsip-prinsip keadilan (al-adalab) dalam masyarakat Madinah yang sekarang dikenal dengan Hak Asasi Manusia (HAM) itu sudah mengajarkan asas-asas globalisasi (Thohir 2014:278).

Menurut Anthony Giddens (1990:67), semakin majunya ilmu pengetahuan dan teknologi di era globalisasi ini, dunia saat ini telah lepas kendali, sehingga perkembangan dunia kini telah jauh dari perkataan semula. Mengapa terjadi, salah satu kata kunci yang menyebabkan kondisi demikian adalah globalisasi. Globalisasi sebagai anak kemajuan ilmu dan teknologi, pada gilirannya memunculkan pelbagai risiko dan ketidakpastian baru yang melampaui kemampuan antisipasi kita. Perubahan dahsyat ini telah merombak tradisi bahkan agama yang selama ini menjadi pijakan banyak orang. Tidak berhenti di situ saja, proses itu mentransformasikan nilai-nilai dalam keluarga dan juga negara (Rismawati 2012:25-26).

Globalisasi dengan ciri khusus adanya interaksi dan integrasi, pada akhirnya memengaruhi perubahan dunia di segala bidang kehidupan. Perubahan dunia beserta paradigmanya sebagai dampak dari globalisasi menunjukan sebuah proses multidimensi yang menuju pada sebuah tatanan dunia tanpa batas pemisah antarnegara (borderless). Sistem sosial demikian memberi dampak baik negatif maupun positif, pada perubahan sosial budaya suatu masyarakat di sudut manapun termasuk juga bagi Indonesia sebagai komunitas masyarakat global (Thohir 2014:279).

Jika dilihat dari akar kemunculan globalisasi yang sampai saat ini menjadi fenomena yang tidak habisnya menjadi diskursus dan perdebatan, globalisasi bukanlah fenomena baru dalam sejarah peradaban dunia. Ciri khas dari globalisasi adalah keterbukaan dan kerelaan dalam menerima pengaruh budaya lain. Hal ihwal ini sudah terjadi beribu-ribu tahun yang lalu sebagaimana dalam sejarah bangsa Romawi, ketika bangsa Romawi berhasil menaklukan bangsa Visigoth, maka bangsa Visigoth pada masa kekaisaran Romawi menuntut hak yang sama sebagaimana yang dimiliki oleh penakluk. Mereka menginginkan hak untuk memilih perwakilan dan perlindungan dari segi undang-undang yang serupa dengan bangsa Romawi, dengan argument "Civis Romanus Sum”, “Aku ini rakyat Romawi”. Atas kesadaran ini, Kaisar Marcus Aurelius (121-180 SM) yang terkenal karena pemikirannya yang cukup modern dalam bukunya berjudul Meditations, membuka kerakyatan Romawi kepada semua etnik dan bangsa dari Dubrovnik di Balkan, hingga ke Colonia di utara Sungai Rhine, sampai ke Kepulauan Britania. Kejayaan Romawi berlandaskan sikap keterbukaan golongan pemerintah terhadap konsep globalisasi. Selanjutnya, globalisasi Romawi telah membawa penerimaan budaya dominan masyarakat Italia Tengah. Bahasa Roma dipergunakan hingga ke penghujung Benua Eropa. Dalam bahasa, perkataan-perkataan Romawi mulai dipergunakan di Persia dan Semenanjung Arab (Khotimah 2009:115).

Melihat dari perkembangan globalisasi yang yang sangat cepat terjadi, maka kita sebagai manusia harus mampu mencermati isu-isu kontemporer yang menjadi permasalahan dunia hingga saat ini khususnya umat muslim, agar bisa menjadikan globalisasi sebagai media entitas dari eksistensi umat muslim, khususnya untuk 
Nalar: Jurnal Peradaban dan Pemikiran Islam

Vol. 2, No. 2, Desember 2018

mendakwahkan ajaran Islam yang toleran, adil, bebas, saling menghormati, kasih sayang, dan sebagainya yang sekarang dirasa kurang memberikan pengaruh dan sumbangsih global terhadap pemahaman secara universal dibanding dengan agamaagama besar dunia lainnya. Oleh sebab itu, tulisan ini akan memaparkan isu-isu kontemporer dalam dunia Islam dari sudut pandang globalisasi sebagai fenomena yang harus dicermati secara seksama agar umat muslim mampu berkompetensi untuk memperebutkan pengaruh hegemoni dunia sekarang ini dengan cara mendekati (approach) objek globalisasi, sebagai struktur makna, dapat diungkapkan secara jelas, yaitu istilah globalisasi dianggap memiliki kesejajaran, titik pijak, dan dimensi kacamata dalam istilah popular (Ratna 2010:45).

\section{Sejarah Perkembangan Globalisasi}

Secara kronologis munculnya globalisasi yang dipahami secara historis melalui munculnya suprateritorialitas yang dimulai dengan munculnya agama di dunia (500 SM), di mana agama mulai memberikan pengaruhnya kepada umat manusia, setelah Christopher Colombus menemukan Benua Amerika (1492 M) dan Vasco da Gama menemukan jalan ke Timur melalui Tanjung Harapan (1498 M) yang merubah Bangsa Eropa mulai menanamkan pengaruhnya di wilayah lain. Munculnya teknologi mutakhir seperti telegraf, pengenalan sistem kesatuan waktu dunia yang berpusat di Greenwhich (1884), munculnya berbagai media seperti radio, televisi, komputer, munculnya perusahaan multinasional seperti McDonald's, konferensi-konferensi internasional, dan perkembangannya berlanjut pada institusi ekonomi global tahun 2000 (Yatim 2017:174).

Istilah globalisasi muncul sekira 1980-an dan diterima secara luas tahun 1990an, tetapi proses yang digambarkannya jauh lebih tua. Jika kita mendefinisikan sebagai hubungan antara orang-orang di berbagai belahan dunia yang semakin erat, maka jelaslah ini telah berlangsung selama ribuan tahun, meski mungkin telah dipercepat dalam dua atau tiga dekade terakhir. Beberapa analis, seperti sejarawan Britania Raya Chistopher Bayly, membagi proses itu atas tiga tahapan: (1) globalisasi kuno, (2) diikuti oleh proto globalisasi dari abad ke-17 dan ke-18 (ketika perusahaan East Indies Belanda dan Inggris sudah menjadi perusahaan antarbangsa), (3) globalisasi modern kurun waktu 1800-1950, dan globalisasi pasca kolonial. Kesemuanya memiliki karakteristik yang mirip, di mana globalisasi ditandai dengan mulai munculnya kemudahan akses interaksi dan komunikasi antara kelompok masyarakat yang ada di berbagai pelosok dunia, tanpa ada dinding pemisah yang menghalanginya. Di sisi lain, perkembangan globalisasi tidak menunjukkan pengaruh yang signifikan terhadap dunia hingga era 1960an. Sejumlah sejarawan telah menekankan pentingnya abad ke-19 akhir sebagai titik balik, tidak hanya dalam sejarah pasar dunia melainkan juga dalam komunikasi global. Seperti ditekankan oleh Braudel (1902-1985), perubahanperubahan yang berbeda berlangsung dengan kecepatan yang berbeda-beda pula. Pada abad ke-19 misalnya, negara dibangun jauh lebih cepat daripada identitas nasional. Seperti diungkap salah satu pemimpin politik, karena telah membuat Italia, sekarang orang Italia perlu dibuat. Dalam cara yang serupa, upaya-upaya untuk menciptakan identitas Eropa telah dipecahkan. Hal ini kemudian diambil alih oleh peristiwaperistiwa, atau lebih tepatnya oleh sebuah tren, tren menuju globalisasi (Burke 2015:285). 
Nalar: Jurnal Peradaban dan Pemikiran Islam

Vol. 2, No. 2, Desember 2018

Hasil penelitian dari The Centre of National Research of France menyatakan, bahwa dunia dewasa ini tengah memasuki perkembangan baru globalisasi. Globalisasi pertama adalah globalisasi politik yang dimulai dengan terbentuknya persatuan bangsa-bangsa (PBB) tahun 1945 yang merubah seluruh tatanan politik yang bersifat global. Globalisasi kedua adalah globalisasi ekonomi yang diperkirakan dimulai pada pertengahan 1970-an, yakni ditandai dengan lahirnya pelbagai kesepakatan (agreement) antarnegara seperti APEC, AFTA, NATO, dan lain-lain. Globalisasi ketiga adalah globalisasi budaya yang dimulai pada 2000-an. Pertemuan antarlintas budaya yang sering terjadi mengakibatkan penguatan budaya lokal karena setiap bangsa ingin mempertahankan budayanya sendiri. Agaknya periode tenggang waktu munculnya tahap globalisasi mengikuti siklus 30 tahunan, sehingga dapat diprediksi di tahun 2030an kemungkinan besar dapat terjadi globalisasi di bidang pendidikan, ditandai dengan banyaknya perguruan tinggi asal negara maju yang memiliki cabang di sejumlah negara lain. Globalisasi keempat adalah identitas kultural. Harus dipahami, kekuatan-kekuatan penggerak globalisasi memiliki agenda untuk melancarkan homogenisasi identitas, negara berkembanglah yang menjadi mangsa yang menjadi makanan negara maju. Oleh sebab itu, dewasa ini kita dapat merasakan betapa mewabahnya nilai-nilai budaya asing bersemayam dari dalam seperti jamur bermekaran di musim hujan. Sehingga identitas budaya negara berkembang lambat laun akan terkikis dan memilih budaya asing tersebut. Hal ini mengindikasikan bahwa globalisasi telah mengancam eksistensi kelestarian identitas kultural yang dianut oleh masyarakat suatu negara khususnya negara berkembang. (Mubah 2015:9).

Terdapat kekhawatiran bahwa ketika pendidikan di negara-negara sekuler mengendalikan dunia pendidikan, maka isu sekulerisme semakin sulit diatasi yang mungkin bertentangan dengan ajaran umat muslim yang ada di Indonesia sebagai agama mayoritas maupun di dunia. Perkembangan ini menjadi tantangan sekaligus jawaban bagi lembaga pendidikan yang berlabel agama (Islam) yang ada di Indonesia maupun di seluruh dunia, agar mampu menjaga eksistensi mereka sehingga mampu bersaing dengan pengaruh perkembangan pendidikan. Sehingga terdapat kebutuhan mendesak untuk merealisasikan sebuah sintesa pendidikan agama, sains, dan teknologi untuk menghidupkan intelektualitas di negara-negara yang menerapkan pendidikan yang bernapaskan agama yang relatif telah lama stagnan. Karakteristik perkembangan masyarakat pada era globalisasi budaya diprediksikan tidak akan linear lagi, namun akan penuh dengan diskontuinitas dan ketidakpastian. Jika dunia pendidikan agama gagal dalam merespon pengaruh globalisasi yang sangat deras dalam perkembangan globalisasi budaya ini dengan daya intelektualitas yang memadai, mudah untuk mendorong kelompok-kelompok primordial dengan paham puritan-radikal untuk muncul ke permukaan seperti dengan kemunculan gerakan Al-Qaeda, ISIS (Islamic State Iraq and Syiria) dan perlawanan kelompok-kelompok radikal yang lainnya. (Arif 2012:1).

Dengan kemunculan gerakan-gerakan itu, serta dibentuknya berbagai organisasi-organisasi berskala internasional yang digagas oleh negara-negara penganut sekuler, maka pola dunia yang sudah didasari oleh kemajuan teknologi komunikasi tersebut pada akhirnya menciptakan globalisasi konsep sekuler atau sekulerisasi global. Disebut globalisasi sekuler, karena pusat-pusat informasi dunia dikuasai dan dikelola oleh negara-negara atau bangsa-bangsa sekuler khususnya dalam dunia pendidikan yang mengubah paradigma seseorang dalam menanamkan pengaruh ideologinya terhadap bangsa lain, seperti Amerika Serikat dan negara-negara Eropa Barat. Celakanya, bahwa pusat-pusat informasi di negara-negara berkembang khususnya 
Nalar: Jurnal Peradaban dan Pemikiran Islam

Vol. 2, No. 2, Desember 2018

mayoritas yang beragama Islam ternyata hanya mampu berperan sebagai penerima pusat informasi dunia saja, sehingga konsep sekuler dari "pusat" dengan serentak berkembang secara "mendunia". Dari kausalitas di atas, kita boleh berharap bahwa sebuah pendekatan sejarah dan teori sosial yang lebih global kita dapat memfilter pengaruh globalisasi yang semakin kencang agar entitas nilai-nilai lokal tidak terkikis oleh nilai-nilai luar yang sudah bersifat global (Warsito 2007:58).

\section{Islam Sebagai Ajaran Global}

Islam sebagai ajaran yang global merupakan ajaran yang telah ada sejak zaman Nabi Muhammad saw. hingga sekarang, perihal ini bisa dibuktikan dengan perkembangannya dalam beberapa massa. Periode pertama, dimulai dari sejak abad ke1 hingga abad ke-7 H, saat peradaban Islam berada pada zaman keemasannya (golden age), sejak Islam tumbuh berkembang dan mencapai puncaknya pada abad ke-4 H. Selanjutnya, Periode kedua, adalah masa pertempuran intelektual antara al-Ghazali (1058-1111 M) terhadap ilmu-ilmu rasional dan Ibnu Rusyd (1126-1198 M) pada abad ke-7 H tidak berhasil untuk mengembalikan kehidupan umat muslim ke dalam kejayaan peradabannya. Periode ketiga, ditandai dengan kemunculan sejarawan Ibnu Khaldun (1332-1406 M) pada abad ke-8 H yang menulis sejarah periode pertama dari masa permulaan dan perkembangan hingga keruntuhan Islam. Setelah itu, ketika reformasi dalam Islam mulai bermunculan secara global dalam dunia Islam, dimulai dengan Jamaludin Al-Afgani (1838-1897 M), ketika Islam menghadapi kekuatan kolonialisme dari luar dan intimidasi dari tubuhnya sendiri, dilanjutkan oleh Muhammad Abduh (1849-1905 M), dengan meninggalkan pemberontakan dan berkampanye menuju reformasi agama, pendidikan, moral, bahasa dan syariah dalam jangka waktu yang panjang telah gagal. Setelah itu, lahirnya gerakan salafi yang menyerukan untuk berpegang teguh kepada tradisi di bawah pimpinan Rasyid Ridha (1865-1935 M) yang membuat arus reformasi dalam dunia Islam akibat pengaruh globalisasi budaya Barat. Setelah ketiganya tidak berhasil untuk menangkal arus negatif globalisasi menyerang dunia Islam, maka Sayid Quthb (1906-1966 M) mengemukakan gagasannya tentang konsep keadilan sosial dalam Islam yang menolak ideologi sekulerisme, liberalisme, nasionalisme, nasserisme, atau marxisme (Hanafi 2015:61). Berkaitan dengan munculnya beberapa reformis-reformis dalam dunia Islam yang ingin membuat dunia Islam secara global maka umat muslim harus bisa menyesuaikan dengan kondisi sosial yang ada sesuai dengan jiwa zaman (zeitgeist), yaitu universalisme Islam.

Dalam globalisme atau universalisme Islam, dua istilah itu merupakan sebuah pemahaman yang berangkat dari fakta tekstual historis, bahwa risalah Islam ditujukan untuk semua umat, segenap ras dan bangsa, serta untuk semua lapisan masyarakat. Ia bukan risalah untuk bangsa tertentu yang beranggapan bahwa dialah bangsa terpilih, dan karenanya semua manusia harus tunduk kepada Sang Maha Kuasa. Jika dilihat dari sejarah Islam yang 'tumbuh', meskipun pada awalnya berada di dalam tubuh suatu bangsa, sekelompok bangsa atau hanya sekelompok individu, ia adalah satu dalam arti, bahwa ia meliputi seluruh umat manusia. Oleh karenanya, berbicara tentang Islam, tidak boleh ada tata sosial Arab atau Turki, Iran ataupun Pakistan, melainkan hanya satu, yaitu tata sosial Islam, walaupun risalahnya diturunkan bermula dari negeri atau kelompok tertentu (Al-Faruqi 1988:110).

Universalisme Islam menampakan diri dalam pelbagai manifestasi penting, dan yang terbaik dalam ajaran-ajarannya (Rais 2001:307). Ajaran Islam mencakup aspek 
Nalar: Jurnal Peradaban dan Pemikiran Islam

Vol. 2, No. 2, Desember 2018

akidah, syariah, dan akhlak kebebasan dalam pemerintahan -yang di dunia Barat dikenal dengan istilah demokrasi -Islam sudah diterapkan sejak era Rasulullah mengenai persamaan dihadapan undang-undang, kebebasan kepercayaan dalam mengatut agama, mewujudkan keadilan sosial, dan lain-lain, atau jaminan atas hak-hak tertentu, seperti hak hidup, berkebebasan dan bekerja, dan sejenisnya, tentunya tidak diragukan lagi, seluruh prinsip dan hak tadi terwujudkan dan terjamin dalam sistem Islam (Rais 2001:307). Dalam ajaran Islam, persoalan kemanusiaan merupakan risalah utama dari enam tujuan syariah, yaitu: menjamin keselamatan agama, badan, akal, keturunan, harta, dan kehormatan. Selain itu, risalah Islam juga menampilkan nilai-nilai kemasyarakatan (social values) yang luhur, yang bisa dikatakan sebagai tujuan dasar syariah, yaitu keadilan, persaudaraan (ukhuwah), kebebasan, dan kehormatan (Qardhawi 1993:422).

Dalam universalisme Islam, ada tiga ranah yang saling dipertautkan dalam rangka universalisme Islam menyambut globalisasi, yakni: ulum al-din (Ilmu-ilmu Agama), dirasah al-islamiyah (Kajian Islam), dan al-fikr al-Islam (Pemikiran Islam). Dalam hal ini Studi Islam (dirasah Islamiyah), dan penelitian sosial keagamaan pada umumnya yang memerlukan pembaruan seiring dengan problem masyarakat secara global. Kompleksitas persoalan mendorong hadirnya beragam tawaran pendekatan, bahkan tawaran paradigma (Rais 2001:309).

Berkaitan mengenai globalisasi pemikiran Islam, selalu mengalami perubahan dan perluasan keilmuan. Setidaknya, dalam pandangan sejarah terdapat lima tipologi pemikiran Islam berdasarkan masa dan dominasi pemikiran saat itu. Pertama, tipe Revivalis-Fundamentalis, yaitu kelompok pemikiran yang mempercayai sepenuhnya doktrin Islam sebagai alternatif utama kebangkitan umat manusia secara global. Bagi mereka, umat muslim terbelakang karena mereka justru menggunakan ideologi lain sebagai dasar pijakan daripada menggunakan Alquran sebagai acuan dasar. Globalisasi dan kapitalisme bagi mereka merupakan salah satu agenda Barat dan konsep nonIslami yang dipaksakan pada masyarakat muslim. Kedua, tipe tradisionalistik (salafi), yaitu kelompok pemikiran yang memegang teguh pada tradisi-tradisi yang telah mapan. Mereka mempercayai, bahwa kemunduran umat muslim dalam arus globalisasi adalah ketentuan dan rencana Tuhan. Hanya Tuhan Yang Maha Tahu tentang arti dan hikmah di balik kemunduran dan keterbelakangan umat muslim (Hakim \& Mubarok 2011:194). Secara kolektif, mereka melakukan Islamisasi dalam segala aspek kehidupan. Ketiga, tipe reformistik, yaitu kelompok pemikiran yang berusaha merekonstruksi ulasan warisanwarisan budaya Islam dengan cara memberi tafsiran-tafsiran baru. Keempat, tipe posttradisionalistik, yaitu kelompok pemikiran yang berupaya mendekonstruksi warisanbarisan budaya Islam berdasarkan standar-standar modernitas. Kelima, tipe modernistik, yaitu kelompok pemikiran yang hanya mengakui sifat rasional ilmiah dan menolak cara pandang agama serta kecenderungan mistis yang tidak berdasarkan nalar praktis (Muammar \& Hassan 2012:133).

Dari globalisasi pemikiran Islam itu, maka dapat ditarik sebuah pemahaman dan jawaban, bahwa dengan berkembangnya arus perubahan yang terjadi di dunia secara global (universal) maka semua risalah yang ada di dalam ajaran Islam sudah mampu menjawab tantangan dan jawaban (challenge and response) seperti yang terjadi sampai sekarang mengenai perubahan yang terjadi sangat cepat berkaitan dengan budaya, ilmu pengetahuan dan teknologi, agama, sosial, politik, dan lain sebagainya. 
Nalar: Jurnal Peradaban dan Pemikiran Islam

Vol. 2, No. 2, Desember 2018

\section{Perkembangan Ilmu Pengetahuan Islam Global}

Islam merupakan agama bagi bangsa-bangsa yang tersebar di pertengahan bumi yang secara keseluruhan jumlah mereka mencapai lebih dari 1.000.000.000 jiwa. Dari sisi latar belakang etnis, Bahasa adat, organisasi politik, pola kebudayaan, dan teknologi, mereka menampilkan keragaman kemanusiaan, namun Islam menyatukan mereka. Meskipun seringkali tidak menjadi totalitas kehidupan mereka, namun Islam terserap dalam konsep, aturan keseharian, memberikan tata ikatan kemasyarakatan, dan memenuhi hasrat mereka meraih kebahagiaan hidup. Lantaran keberagaman itu, Islam berkembang menjadi keluarga terbesar umat manusia (Lapidus 2000:7).

Berkelindan dengan umat muslim yang menjadi salah satu keluarga terbesar umat manusia, maka banyak sekali melahirkan para cendekiawan-cendekiawan dari masa ke masa, di antaranya: ulama zaman klasik, yaitu zaman antara abad ke-8 dan ke$13 \mathrm{M}$, mereka tidak hanya menguasai keilmuan di bidang agama, tetapi juga merambah kepada keilmuan 'sekuler' (sains), seperti kedokteran, matematika, astronomi, kimia, optika, geografi, dan sebagainya. Nama-nama yang termasyhur dalam ilmu kedokteran ialah al-Thabari (abad ke-9), al-Razi (865-925), Ibnu Sina (980-1037 M), dan Ibnu Rusyd (1126-1198 M). Selain Ibn Rusyd di Andalusia atau Spanyol, Islam juga dikenal sosok al-Zahrawi sebagai ahli bedah pada abad ke-19 M. Dari keturunan Ibn Zur muncul dokter perempuan. Dalam bidang matematika dikenal al-Hawarizmi (750-850 M), bapak ilmu aljabar. Kata algoritme dalam matematika berasal dari al-Khawarizme ini. Nama-nama lain adalah 'Umar al-Khayyam, al-Thusi, al-Kindi, al-Mahani, dan alQuhi yang mengarang buku dengan judul Tambahan terhadap Buku Archimedes. Angka Arab dibawa ke Italia dan Afrika pada permulaan abad ke tiga belas, maka angka yang sekarang dipakai di Eropa dikenal dengan angka Arab, untuk membedakannya dengan angka Romawi. Angka nol adalah ciptaan ahli matematika Arab yang dalam bahasa Arab disebut shifr. Kata ini menjadi cipher dalam Bahasa Inggris.

Astronom Islam pertama adalah al-Farizi (w. 777 M). Astronom-astronom lain adalah al-Farghani, al-Battani, al-Thusi, 'Umar al-Khayyam (1048-1131 M), dan beberapa kota di Spanyol Islam. Al-Battani (858-929 M), misalnya, melakukan koreksi terhadap karya-karya Ptolomeus, sedangkan kalender yang dibuat 'Umar al-Khayyam dipandang lebih tepat dari kalender yang dibuat Gregorius. Bapak ilmu kimia Islam ialah Ibn Hayyan (721-815 M). Dia mengarang kitab mengenai konsentrasi air raksa. Nama besar di bidang ilmu pengetahuan optika adalah Ibnu Haytsam, yang dalam bukunya menentang teori Euclid dan Ptolomeus, bahwa benda dapat dilihat karena mata mengirim cahaya ke dalam benda itu. Teori Ibn Haytsam adalah sebaliknya, benda dapat dilihat karena benda mengirim cahaya ke mata. Sementara dalam geografi, nama al-Khawarizmi juga pernah memberikan sumbangsih terhadap ilmu pengetahuan. Dia mengarang kitab berjudul Surat al-'Ardh (Peta Bumi), yang mendedahkan tentang peta dunia Islam pada zamannya. Al-Mas'udi mengelilingi dunia sampai ke Nusantara, dan demikian juga Ibn Bathutah.

Dalam ilmu pengetahuan alam, ulama-ulama Islam menulis tentang ilmu hewan, ilmu tumbuh-tumbuhan, antropologi, geografi, geologi, dan lain-lain. Namanama yang masyhur dalam bidang ini adalah al-Jahiz, Ibn Sina, Ibnu Miskawih, alQuzwuni, Ikhwan al-Shafa, dan lain-lain. Teori evolusi tujuh abad sebelum Darwin telah dikemukakan oleh al-Jahiz, Ibn Miskawih, dan Ikhwan al-Shafa. Menurut teori ini, alam mineral lebih dahulu ada, kemudian alam tumbuh-tumbuhan, lalu alam hewan 
Nalar: Jurnal Peradaban dan Pemikiran Islam

Vol. 2, No. 2, Desember 2018

dan terakhir alam manusia. Evolusi dari alam mineral ke alam tumbuh-tumbuhan terjadi melalui merjan, dari tumbuh-tumbuhan ke alam hewan melalui pohon kurma, dan dari hewan ke alam manusia melalui kera. Begitu pula ilmuwan lainnya, seperti Ali al-Hasan Ibnu Haitam (965-1038) yang menemukan ilmu pasti, Abu Raihan Ibnu Ahmad al-Baruni (973-1051 M) dalam bidang ilmu falak, Muhammad al-Syarif al-Idrisi (1100-1166 M) dalam bidang ilmu bumi alam, abu Zakariyya Yahya Ibnu Awwam (w. 1185 M) dalam bidang pertanian, Abu Usman Amr Ibnu Bahr al-Jahiz (776-869 M) dalam bidang ilmu hewan (Zar 2004:442).

Zaman Pertengahan, universitas-universitas didirikan di Dunia Islam. Ke sanalah mahasiswa-mahasiswa dari Prancis, Inggris, dan lain-lain datang menuntut ilmu yang dikembangkan ulama-ulama Islam itu. Di antara mahasiswa itu adalah Roger Bacon dan Michael Scott. Buku-buku karangan ulama Islam diterjemahkan ke dalam Bahasa Latin, dan Toledo menjadi pusat penerjemahan. Penerjemah-penerjemah terkenal adalah Adelard Bath, Gerard Cremona, dan lain-lain. Pada penutup abad ke$13 \mathrm{M}$, filsafat dan sains yang dikembangkan ulama Islam itu telah berpindah ke Eropa. Akibatnya, Renaisans pun timbul di benua itu. Dari sini bisa dilihat bahwa peran intelektual muslim sangat besar, sehingga orang-orang Eropa memiliki peradaban. Merekalah yang menjadi guru orang Eropa selama enam ratus tahun (Harun Nasution, 1998:34).

Zaman modern, dimulai sejak abad ke-19 sampai fajar millennium ketiga, dunia Islam yang membentang dari Maroko (Afrika Utara) sampai Nusantara (Indonesia) sedang dilanda sorak-sorai gemuruh pesta kebangkitan Islam. Dunia Barat di satu sisi, menatapnya dengan penuh harap, senyuman, dan antusiasme. Ada semacam keyakinan kaum muslimin, bahwa kebangkitan Islam adalah suatu proses yang taken for granted. Hal ini diperkuat oleh pengakuan banyak pengamat, sarjana Barat maupun Timur, bahwa fenomena kebangkitan Islam tidak hanya terjadi secara historis, sosiologis, dan politis, tetapi juga sebagai proses natural. Pencarian akan identitas Islam, dan formulasi respon-respon Islam atau alternatif-alternatif terhadap tantangan globalisasi dapat disaksikan abad ke-20. Dan pencarian, dan usaha-usaha pemunculan Islam sebagai alternatif ini sudah merupakan sebuah fenomena global (Syracuse 1987:1).

Berkaitan dengan perkembangan pengetahuan Islam yang sudah tertinggal, maka umat muslim bangkit untuk berkompetensi secara global dengan munculnya ide kebangkitan Islam didorong oleh beberapa faktor. Evers dan Siddique (Evers \& Shidique 1993:1-2). mencatat ada empat model gerakan yang melatarbelakangi revivalisme keagamaan: pertama, gerakan penolakan atas rasionalisasi, yaitu penolakan terhadap "demistifikasi dunia"; kedua, gerakan sebagai usaha mengatasi tekanantekanan modernisasi; ketiga, gerakan anti-imperialis dan anti-hegemoni; keempat, sebuah gerakan pembaharuan yang notabene adalah doktrin agama itu sendiri. Secara umum, kata mereka, empat perspektif gerakan ini dikembangkan dalam ilmu pengetahuan (sains), ekonomi, politik, dan agama secara berurutan sebagai respon globalisasi yang sudah menjadi fenomena di mata umat muslim (Voll 2003:5-6).

\section{Posisi Islam dalam Globalisasi}

Dari pemaparan di atas, dapat dipahami, bahwa secara prinsip, Islam sangatlah relevan sebagai ajaran global. Persoalannya kemudian, bagaimana memosisikan Islam dalam percaturan globalisasi? Dalam hal ini, dapat digarisbawahi bahwa Islam sebagai ajaran global yang memiliki ajaran universal merupakan bagian yang tidak bisa 
Nalar: Jurnal Peradaban dan Pemikiran Islam

Vol. 2, No. 2, Desember 2018

dipisahkan dari globalisasi. Menyikapi problema globalisasi, maka prinsip-prinsip ajaran Islam yang universal bisa dijadikan dasar berpijak bagi umat muslim. Di sinilah, pemafhuan yang tepat terhadap nash menjadi syarat yang harus dipenuhi. Islam pada prinsipnya satu secara akidah, tetapi pada bidang-bidang yang lainnya, boleh jadi berbeda, atau malah bertentangan. Namun demikian, semua itu secara keseluruhan tetap berada dalam naungan Islam. Dalam menyikapi globalisasi ekonomi yang merupakan bagian dari realita saat ini, Islam sebagai sebuah ajaran moralitas memberikan batasan-batasan agar tidak terjadi eksploitasi antara manusia yang satu dengan yang lain. Islam menghendaki persamaan (musawwah) atas prinsip harta tidak hanya beredar di kelompok-kelompok tertentu saja. Perilaku ekonomi Islam bertujuan untuk menyejahteraan semua pihak. Prinsip utama dari ekonomi Islam di era global adalah: (1) Tauhid: keesaan dan kedaulatan Allah Swt. Konsepsi ini menuntut adanya kepatuhan terhadap aturan-aturan yang telah ditetapkan tanpa syarat. Dalam konsepsi ini, eksistensi manusia dipersatukan dalam ketaatan kepada Allah, yang akan berimplikasi pada aktivitas ekonomi, yaitu tidak ada diskriminasi. (2) Keadilan: hal ini penting karena keadilan menjadi suatu titik tolak dalam membangun kesejahteraan hidup. Dari sini akan muncul kedinamisan dalam kehidupan berbangsa dan bernegara. (3) Tanggung jawab: dalam prinsip ekonomi Islam, setiap pelaku ekonomi harus bertanggung jawab, baik dari sisi akses ataupun aktivitasnya kepada diri sendiri dan masyarakat ataupun bangsa. Demikian juga tidak dibolehkan terjadi kerusakan ekologi sebagai akibat manfaat teknologi yang berlebihan. Prinsip ekonomi Islam ini muncul dalam rangka melakukan kritik dan solusi atas banyaknya kekurangan yang terdapat dalam ekonomi kapitalis (Nagwi 1993:50-51).

Pada aspek budaya, Islam memiliki kebudayaan sendiri yang kosmopolit, tetapi Islam juga mengakui eksistensi kebudayaan lokal. Kosmopolitanisme budaya Islam dibentuk oleh budaya lokal, tempat Islam itu tersebar. Sebagai bukti konkret, kita mengenal Islam Jawa, Islam Madura, Islam Iran dan lain sebagainya, yang meskipun secara kultur tidak sama, tetapi tetap dalam kesatuan Islam. Islam pada waktu berasimilasi yang membentuk tatanan kebudayaan baru yang khas. Pada aspek pendidikan, tawaran yang hendak disampaikan oleh Islam adalah pendidikan yang integralistik. Berbeda dengan pendidikan umum dewasa ini, Islam tidak menghendaki dualisme pendidikan. Pendidikan selain diperuntukkan untuk mencapai 'kebahagiaan' dunia, juga seyogyanya diwarnai dengan nilai-nilai transendensi kepada Sang Maha Pendidik, yaitu Allah Swt. Pendidikan seharusnya mengutamakan kepentingan moralitas sebagai bagian yang esensial dalam tata kehidupan manusia. Namun, tidak berarti antipati terhadap modernisme yang merupakan produk Barat. Oleh karena itu, pendidikan merupakan sistem bagi pengembangan ilmu pengetahuan dan teknologi (IPTEK) yang berangkat dari ajaran alquran dan sunah, sebagai pembaharuan pemikiran yang dapat merespon tantangan zaman tanpa mengabaikan aspek teologis dogmatis, dan sebagai sarana untuk menumbuhkembangkan sikap dan mental manusia yang benar-benar bertakwa kepada Tuhan YME tanpa mengenal batas akhir. (Nagwi 1993:31).

Pada aspek teknologi, Islam menghendaki teknologi yang tepat guna, dalam arti, tidak hanya memberikan kemudahan dan kenyamanan, tetapi juga tetap menempatkan manusia sebagai subjek penentu. Teknologi juga tidak boleh mengeksploitasi alam secara membabi buta sehingga merusak ekosistem yang ada. Globalisasi yang berangkat dari penggunaan teknologi yang merusak ekologi inilah yang dilarang dalam Islam. Pada aspek seni, terutama seni musik yang relatif paling 
Nalar: Jurnal Peradaban dan Pemikiran Islam

Vol. 2, No. 2, Desember 2018

cepat perkembangannya dibanding dengan seni yang lain, suasana globalnya sangatlah nampak, suatu bentuk musik yang menjadi top di suatu wilayah bisa dengan cepat diadopsi wilayah lain, sebagaimana yang terjadi dalam dunia mode dan pakaian. Oleh sebab itu, penyebaran dari aspek yang disebutkan di atas, kita harus memfilternya agar pengaruh globalisasi tidak membawa dampak yang negatif secara signifikan.

\section{Penutup}

Islam sangat fleksibel dengan perubahan zaman yang sangat cepat terhadap perilaku globalisasi. Oleh karenanya, globalisasi sebagai bagian dari proses sejarah umat manusia yang merupakan fakta historis yang tidak bisa ditolak, yang memberikan pengaruh yang luar biasa dalam perubahan tatanan kehidupan masyarakat di dunia, khususnya dunia Islam. Sebagai bagian dari dunia Islam, Islam merupakan agama yang bersifat gobal-universal, yang memiliki universalitas ajaran yang bisa dipergunakan untuk mewarnai kehidupan masyarakat secara global. Maka, perhatian yang komprehensif terhadap ajaran-ajaran Islam yang bersifat universal, merupakan suatu niscaya agar Islam bisa memberikan kontribusi nyata yang berarti bagi peradaban global seperti masa kejayaan Islam.

Universalitas ajaran Islam tidak berarti mematikan potensi budaya lokal, tetapi entitas budaya lokal tetap diakui sehingga Islam adalah agama yang bisa menyesuaikan dengan keadaan di masyarakatnya, tetapi nilai-nilai ajaran Islam tidak berubah. Jika melihat peradaban Islam yang dibangun oleh founding father-nya, Nabi Muhammad saw. Pada 14 abad yang lalu mengenai nilai ketakwaan, persamaan, keadilan, dan kreativitas dari dalam diri Islam yang universal dengan akulturasi timbal balik dari budaya lokal, maka Islam adalah satu-satunya agama yang paling sempurna ajarannya dibanding dengan agama-agama lain di dunia. Oleh karena itu, kesempurnaan itu melahirkan universalisme Islam dapat berperan dalam menyikapi problem globalisasi dan menjadi pijakan bagi umat muslin maupun umat yang lainnya dalam bidang ekonomi, pendidikan, kebudayaan, ilmu pengetahuan, dan teknologi. 
Nalar: Jurnal Peradaban dan Pemikiran Islam

Vol. 2, No. 2, Desember 2018

\section{DAFTAR PUSTAKA}

Abdul Hakim, Atang. \& Jaih Mubarok. 2011. Metodologi Studi Islam. Bandung: Remaja Rosda Karya.

Allbrow, Martin. \& Elizabeth King. 1990. Globalization Knowledge and Society. London: Sage Publication.

Antoun, Richard T. \& Mary Elaine Hegland (ed.). 1987. Religious Resurgence, Contemporary Case in Islam, Christianity, and Judaism. Syracuse, Syracuse University Press.

Arif, Faisal. 2012. Agama dan Globalisasi. Jakarta: Binus University Press.

Burke, Peter. 2015. Sejarah dan Teori Sosial. Jakarta: Yayasan Pustaka Obor Indonesia.

Dewi Rismawati, Sinta. 2012. "Pengaruh Globalisasi terhadap politik Hukum berbasis perlindungan hak Asasi Manusia (HAM) di Indonesia" dalam Hukum Islam: Jurnal Hukum Islam, Vol. 10 Nomor I Edisi Juni.

Evers, Hans-Dieter. \& Siddique, Sharon. 1993. "Religious Revivalism in Southeast Asian: In introduction". dalam Sojourn: Journal Sojourn Social Issues in Southeast Asian, Vol. 8, No. 2.

Giddens, Anthony. 1990. The Qonsequences of Modernity. Stanford: Stanford University Press.

Hanafi, Hassan. \& Muhammad Abid Al-Jabiri. 2015. Dialog Timur dan Barat. Yogyakarta: IRCisoD.

Jan Aart, Scholte. 2001. The Globalization of the World Politics. London: Oxford University Press.

Jones, Pip. Liz Bradburry, \& Shaun Le Boutillier. 2016. Pengantar Teori-Teori Sosial. Jakarta: Yayasan Pustaka Obor Indonesia.

Khotimah, Khusnul. 2009. "Islam dan Globalisasi: Sebuah Pandangan tentang Universalitas Islam", dalam Komunika: Jurnal Komunika Vol. 3 No. 1 Edisi Januari-Juni.

Kutha Ratna, Nyoman. 2010. Metodologi Penelitian: Kajian Budaya dan Ilmu Sosial Humaniora pada Umumnya. Yogyakarta: Pustaka Pelajar.

Lapidus, Ira M. 2000. Sejarah Sosial Umat Islam Bagian Ketiga. Jakarta: Raja Grafindo Persada.

Muammar, Arfan. Abdul Wahid Hassan, dkk. 2012. Studi Islam Perspektif Insider/Outsider. Yogyakarta: IRCiSoD.

Munawar Rahman, Budhy. 1994. Universalisme Islam dan Kosmopolitanisme Peradaban Islam. Jakarta: Yayasan Paramadina.

Nasution, Harun. 1998. Islam Rasional. Bandung: Mizan.

Nawab Nagwi, Sayyed. 1993. Etika dan Ilmu Ekonomi: Suatu Sintesa Islami. Bandung: Mizan. 
Nalar: Jurnal Peradaban dan Pemikiran Islam

Vol. 2, No. 2, Desember 2018

Qardhawi, Yusuf. 1993. Mad₹khal li al-Dirasat Islamiyah. Beirut: Dar al-Syuruq.

Rais, M. Dhiaudin. 2001. Teori Politik Islam. Jakarta: Gema Insani Press.

Raji Al-Faruqi, Ismail. 1988. Taubid. Bandung: Pustaka.

Safril Mubah, Ahmad. 2015. Isu-isu Globalisasi Kontemporer. Yogyakarta: Graha Ilmu.

Taufik, M. Tata. 2013. "Menelusuri Perilaku Peradaban Global” dalam Tamadun: Jurnal Tamadun Vol. 2 No. 2 Desember.

Thohir, Ajid. 2014. Sirah Nabawiyab: Nabi Mubammad dalam Ilmu Sosial dan Humaniora, Bandung: Marja.

Voll, John. O. dkk. 2003. Asia Tenggara Konsentrasi Baru Kebangkitan Islam. Bandung: Fokusmedia.

Warsito, Tulus. 2007. Wahyuni Kartikasari, Diplomasi Kebudayaan. Yogyakarta: Ombak.

Yatim, Badri. 2015. Sejarah Peradaban Islam. Jakarta: Raja Grafindo Persada.

Zar, Shirajudin. 2004. Filsafat Islam: Filosof dan Filsafatnya. Jakarta: Raja Grafindo Persada. 